\title{
ISLAM
}

\section{IN A SEPTEMBER 11, 2001 PERSPECTIVE}

by Gabriel Lahood

The tragic events of September 11, 2001 that took place in the United States (New York, Washington, D.C., and Pennsylvania) have been linked with Benladen, a Muslim Saudi Arabian extremist leader, acting in the name of Allah and Islam. More recent news linked these events with Saddam Husein, a Muslim Iraqi head of state. For the purpose of this essay, it is not important to prove that some Muslim individuals were the true and efficient authors of the above-mentioned tragedy in order to conclude that if violence is correctly linked with some Muslim individuals, it must also be linked with Islam as a source of violence. Instead of tracing the recent September violence back to Muslim authorities, who may have commended such violence, it would be more fundamental to investigate whether Islam truly teaches the violence associated with the concept of $j$ iha $\bar{a} d$ (Holy War), and then investigate whether jihad is likely to imply a violence similar to that of September 11.

The issue of whether Islam provokes the supposedly jiha $\bar{d}$-related violence will be investigated in the Islamic most sacred texts, the Holy Quran and the next-in-authority, the Sunna or Sunnat al-Nabi (Guidance of the Prophet). Then, the Islamic history will be examined to see how jihād was understood and applied. Once these scriptural and historical foundations are established, the readers should then be able to conclude whether Islam truly instigates the violence allegedly associated with $j i h \bar{a} d$ and consequently with the September violence.

When reading the Qur'an, one will notice terms, epitomized in the coined noun jiha ad, inviting Muslims to "struggle" or "strive" in "Holy War". The verb jāhada, a derivative of jihăd, occurred in the Qur'ān as a command to Muhammad: "O Prophet, strive hard (jähid) against the unbelievers and hypocrites..." (Qur'an, surah 9: verse 73). It also occurred as a command to the Islamic community, Jahadu: “...and fight (jāhadu) for the Faith..." (Q 8:75). The term jiha $\bar{a}$ has inspired several extremist Islamic politico-religious parties, such as the Egyptian Jihad Party that has master-minded the assassination of Egyptian President Anwar Sādāt, the Lebanese Jihad party that was active in the recent Lebanese civil war, not to mention other Jihad parties of the Gulf states and Indonesia, all of which are inspired by the concept of Holy War. Beside the term jihäd, The Qur'an has several other terms that suggest violence.

The Qur'ān prescribes Qitāl (fighting and killing), a derivative of the verb qatala, to kill, and its more forceful verb qătala, to fight (with vigor) and kill. 
Early Islamic community has understood the message to be harsh: "Prescribed for you is fighting, though it be hateful to you." (Q 2:216). This is why they complained about it: "Our Lord! why hast Thou ordered us to fight?" (Q 4:77). It is interesting to notice in Q 2:190 the antagonistic commands of "jihad fighting" and "avoiding aggression" as if to say that "jihād fighting" is meant to be only a response to aggression, and aggression is simply not Islamic: "Fight in the cause of Allah those who fight you, but do not transgress limits; for Allah loveth not transgressors". More specifically, Muslims ought to kill the heretics/pagans (mushrikun): "But when the forbidden months are past, then fight and slay the pagans (Fa'qtulu almushrikun) wherever ye find them, and seize them, beleager them, and lie in wait for them in every stratagem (of war); but if they repent, and establish regular prayers, and practice regular charity, then open the way for them; for Allah is Oft-Forgiving, Most Merciful." (Q 9:5)

Beside the verbs gatala and qâtala, the Qur'an also uses the ambiguous verb daraba that literally means "to hit". However, this term has to be placed in its scriptural and historical contexts, where Muslims are ordered to fight, and fighting in those days meant killing. Thus, "hitting" meant "hitting to kill" and more specifically "hitting to kill with a sword". This command becomes clearer when "hitting" refers to "hitting the necks of the unbelievers." Thus, "hitting" refers to "hitting the necks of the unbelievers with the sword in order to kill them". The verb has been used in the plural form to suggest that the Muslim community, as a group of fighters, are supposed to "kill": "When you meet the unbelievers, smite their necks, then when you have made wide slaughter among them, tie fast the bonds: either by grace or ransom till the war lays down its loads." (Q 4:7:4-5)

It is interesting to notice here that the idea of fighting in order to convert others is a novelty that previous prophets of major religions did not make use of the way the Message of Muhammad conveys it and the way Muhammad and his successors executed it. The recourse to arms was in the Old Testament primarily a means for survival, not for making converts: "The Lord has given you this land to possess... You shall not fear them; for it is the Lord your God who fights for you" (Deuteronomy 3:18-22). In the New Testament, the idea of forceful means to survive or to convert others is rather transcended for a more sublime alternative of loving and forgiving. When Peter pulled his sword to defend Jesus who was about to be arrested, Jesus told him to put his sword back (Jn 18:10-11). And when the Pharisees showed Jesus a coin and asked him whether it should be given to Caesar or to God, he said: "Render therefore unto Caesar the things which are Caesar's; and unto God the things that are God's" (Mt 22:21). He said so in order to make it clear that religion and politics should not mix-which is contrary to what Islam seems to teach. Certainly, one cannot deny that certain Christian (or Muslim) leaders acted contrary to the Christian (or Islamic) teaching. Therefore, one has to distinguish between what a Christian or a Muslim does and what the Gospel or the Qur'an teaches. Also, one needs to recognize that the holy text of a religion, not the act of a religious leader, is to be recognized as the authority. Within this context, one may say that the Holy Qur'an commands also the merging of religion with politics and addresses the Muslim community as a nation ("umma). 
The Qur'ān uses the term 'umma to mean "a community" and "a nation": "Let there arise out of you a band of people ['umma] inviting to all that is good..." (Q 3:104). The term =umma is, however, ambiguous in that it means "a religious community" and "a [political] nation". The Qur'an refers to 'umma as "nation, but even there it is unclear whether the reference is to a political or only a religious entity: "Our Lord! Make of us Muslims, bowing to Thy (Will), and of our progeny a people Muslim ['umma muslima], bowing to Thy (Will)." (Q 2:128) Similarly: "To every people ['umma] did We appoint rites (of sacrifice), that they might celebrate the name of Allah over the sustenance He gave them". (Q 22:34) It is likely that the meaning of the term has shifted from "a religious community" to "a religious as well as political entity". This seems to be confirmed in Muhammad's attitude from the time of his early revelations in Mecca, when he had very few followers, to the time after his migration (hijra) to Medina, when his followers became a military and a political challenge.

A few hadith (Conversations of the Prophet) statements suffice to give an idea that the Prophet Muhammad gave his interpretation of the Qur'ānic term Jihäd as "fighting," or "forceful measure and violence," in the name of Allah. For example, one hadith (dialogue) related by Muslim (817-875 C.E.) in his Sahih (a hadith collection) regards Abu Hurayra having reported Muhammad to have said: "Whoever dies without fighting in the cause of Allah and without even having such an intention in his heart dies possessing one of the signs of hypocrisy". (Kazi 1992, p. 138, nr.344: related by Muslim). The same idea of killing at the cost of being killed is expressed in the following Qur'ānic definition of the true Muslim believer: "Only those are the believers who [truly] believe in Allah and His Messenger and then show no doubt, but strive with their wealth and their lives for the sake of Allah-such are the sincere ones." (Q 49:15) (quoted by Kazi 1992, p. 139, n. 401) Similarly, a hadith related by Al-Tirmidhi (died c. 892), another hadith collector, reports the Prophet having said: "Nothing is dearer to Allah than two drops and two marks. The two drops are the drop of a tear that flows out of fear of Allah and the drop of blood shed in the path of Allah. The two marks are the mark [of a wound] in the cause of Allah and the mark caused by discharging one of the obligatory duties to Allah [e.g. the mark of prostration on the forehead as a result of prayer]." (Kazi 1992, p. 138, nr. 346: related by Tirmidhī). Thus, it seems evident that Muhammad understood and taught Jihād as meaning "war," "forceful measure," and "violence." However, the Jih $\bar{a} d$ of women assumes a different meaning, though not contradicting the Jih $\bar{a} d$ for men fighting in war. Al-Bukhari (810-870), another hadith collector, reports 'Aisha, the Prophet's daughter, having said: "Once I asked the Prophet for permission to take part in Jihäd, and he said, "The Jihäd of women is hajj (pilgrimage)." (Kazi 1992, p. 68, nr. 126: related by Bukhari and Majah) Bukhari reports another hadith in which Jiha $\bar{a} d$ is equated with any humanitarian good deed or an intense prayer: "He who looks after the needs of the widow and the poor is like a warrior fighting in the cause of Allah or like a person who fasts during the day and prays throughout the night." (Kazi 1992, p. 100, nr. 230: related by Bukhari)

When looking at the history of Islam, one will notice a history featured by successive and continued wars and violence. Islamic history, as recorded by early Muslim collectors of HadithTraditions of Muhammad and historians 
displays since its inception events of violence ordered as a religious command of $J i h \bar{a} d$. Such violence first started with the Prophet Muhammad as a means of self-defense, then, gradually became a means to convert the unbelievers. Later, there were $j i h \bar{a} d$ wars of conquest and massive conversions in the time of the immediate successors of Muhammad, the khulafa' alrāshidiun or the Rightly Guided Successors (632-661 C.E.). Then, in the time of the first two Islamic dynasties, the Umayyads (661-750 C.E.) and the Abbasids (750-1258 C.E.), the jihäd wars had a wider geographic perspective and a more focused objective: beside converting the unbelievers, the caliphs wanted to acquire greater worldly rule, power, and wealth. Thus, contrary to their promises to re-establish true Islamic religious and social ideals in the beginning of their rules, both Umayyad and Abbasid caliphs became corrupt by the power and wealth they were acquiring, and were deposed-usually murdered-to yield the throne to other Muslim leaders with Islamic ideals. Then, during the Sultanate era (1258 until WWII), there was a continued concern with worldly, more than with religious, affairs, that invited continued violence. In contemporary times, many Muslim leaders, or heads of states, used the pretext of Islamic jiha $\bar{a} d$ to affirm their political authority. Extremist Muslim factions or parties, such as Hamas (Vigor), Amal (Hope), Intifada (Escalation), Bacath (Revival), Hizbullah (Allah's Party), al-Ikhwan al-Muslimun (Muslim Brotherhood), and others interpret jihād in the litera sense. Thus, highjacking planes, bombing public places, and invading nonIslamic embassies are permissible sample acts of $j i h \bar{a} d$.

The Prophet Muhammad (570-632 C.E.), the greatest caller to Islam and the first and most authoritative individual to interpret the concept of jiha $\bar{a}$, received his first revelation in 610 C.E. at the age of forty, and was persecuted by his Arab fellows for proclaiming a Supreme God replacing the many gods of the Arabian pantheon: Allah. Because of this persecution, - Muhammad migrated in 622 C.E., year one of the Hijri calendar, with a couple of hundred followers from Mecca to Medina to form a politico-religious community of Arabs ('umma) who believed in the One and Only God, Allah, and accepted Muhammad as His Prophet. However, as a means of selfdefense and zeal for spreading the message of Allah, Muhammad resorted to waging $j i h \bar{a} d$ wars against the Meccas and later against other Arab tribes who too were considered infidels (mushrikūn). Obviously the blood shed that took place in those wars made many converts, widows, and jihad martyrs. The Jews and Christians were added to the category of infidels/heretics because they had, supposedly, misinterpreted God's true revelation in their Bible. Thus, waging jihäd wars against such infidels since the time of Muhammad meant aggression, persecution, and bloodshed.

The immediate successors of Muhammad, al-khulaf $\bar{a}^{\prime}$ al-Rāshidūn (The Rightly Guided Caliphs), continued the jihäd mission of the Prophet, which meant not simply to attack and kill non-Muslim infidels but also Muslim rulers who were thought to be erring from the Qur'anic teaching. All of the four Rightly Guided Successors were killed. More particularly, the first caliph Abu Bakr (reigned 632-634 C.E.) died, as tradition relates it, of poisoned food. Umar (r. 634-644 C.E.), the second caliph, "Fell... on Nov. 3, 644 by the dagger of Abu Lu'lu', a Christian slave of al-Mughīra b. Shu'ba, governor of Basra... [because of] the very heavy tax against which the slave had appealed in vain to the caliph." (Sh.E.I. 1953-1974. S. v. "Umar, page 601, col. 1, par. 3, 
line 17) Uthmān (r. 644-656 C.E.), the third caliph who had "appointed members of his family to the governorships in the provinces" (Sh.E. I., s.v. 'Uthman, $615,1,3,11$ ) and who was planning to kill the Muslim leaders who were leading the rebellion against him in Iraq and Egypt, was assassinated by Muhammad son of Abu Bakr, the first caliph. 'Ali (r. 656-661 C.E.), the fourth caliph who was forsaken by at faction, the Kharijites, of his own Shicite party was eventually assassinated by a Kharijite, 'Abd al-Rahman b. Muljam Al-Särimi. The reason of his assassination was that ${ }^{\mathrm{A}} \mathrm{Ali}$ had allowed the arbitration which ended up with $M u^{c}$ äwiya and his representative arbitrator, ${ }^{c} \mathrm{Amr} b$. Al- ${ }^{\mathrm{A}} \overline{\mathrm{A}} \mathrm{s}$, tricking him and making him abdicate his post that was rightfully his.

With the fourth caliph, "Ali, there was a major schism within Islam, the Shicites, followers of ${ }^{c} \mathrm{Ali}$, on one side, and the Sunnites, the opponents of ${ }^{\mathrm{c}} \mathrm{Ali}$ and partisans of $\mathrm{Mu}^{\mathrm{c}}$ awiya and his successors on the other. Violence was the common denominator in the relationship between these two Muslims factions. The murder of Ali was not the only violence that took place then. The two children of 'Ali, Hasan and Husayn, were both murdered, again in the name of jihad, by the Sunnite Muslims. Al-Hasan, 'Ali's older son, who was more interested in women, luxury, and pleasures than in leadership, and to whom Mucawiya had promised a handsome pension, was eventually poisoned by one of the women in his large harem. The other son of ${ }^{\mathrm{c} A l i}$, Husayn, was attacked and killed with his small number of followers in Karbala'in northern present-day Iraq. Thus, jihad was violent and applicable not only when Muslims dealt with non-Muslims, but also when Muslims dealt among themselves. The Shicites and their factions took every opportunity to retaliate the martyrdom of their leaders and Imams, "Ali and his children, not to mention the later Shicite martyrs of the Ismacili, Qarmatian, Assassin, Nusayri, and Druze sects. Thus, both Muslim factions, Sunnites and Shicites acted violently in the name of jihäd.

With the Umayyads (661-750 C.E.), the caliphate became a dynasty that invited jealousy, retaliation, military arrogance, and violence. Just a sample of such violent politico-religious figures is the Umayyad governor al-Hajjaj. This man proved his military achievement and violence in 692 at the age of thirty-one by crushing in battle the powerful cAbdullah ibn Zubayr. More typical of Al-Hajjajj is his horrifying threat and mass-execution of the Shicites in Kufah (northern Iraq): "O people of al-Kufah! Certain am I that I see heads ripe for cutting, and verily I am the man to do it." In fact, "[h] uman lives to the number of 120,000 are said to have been sacrificed by this governor of AlIräq." (Hitti 1943, p. 207, quoting Mubarrad, Kāmil, pp. 215-16; Yacqubi, vol. ii, p. 326; and Mas'ūdi, vol. V, p. 294) More of such violence can be said about other Umayyad caliphs and their generals.

The Abbasid dynasty (750-1258 C.E.) were descendants of an uncle of the Prophet, al-'Abbās ibn 'Abd-al-Muttalib ibn Hāshim, and thus they considered themselves to be closer to the Prophet, and having more right to rule the fast growing Islamic empire, than their predecessors the Umayyads. They challenged and replaced the Umayyad caliphate because these were claimed to have been alienated from the true Islamic ideals and, thus, were to be removed, obviously in the name of jihäd. Although the titles of many Abbasid caliphs were titles with religious connotations, such as al-Muctasim 
(r. 833-842 C.E.), meaning "The One Who Takes Refuge [in God]," al-Wäthiq (r. 842-847 C.E.), meaning "The One Who Is Certain [of God's Assistance], many ended becoming dictators as they became more and more concerned with the political post of leadership and power that some became symbols of "bloodshed." For example, the first Abbasid caliph, Caliph abu-al-Abbas (r.750-754 C.E.), "referred to himself as al-saffah, the bloodshedder, which became his sobriquet. This was ominous, since the incoming dynasy, much more than the outgoing, depended on force in the execution of its policies. For the first time in the history of Istam the leathern spread beside the caliph's seat, which served as a carpet for the use of the evecutioner, becane a necessary adjunct of the imperial throne." (Hitti 1943, p. 288, quoting Tabari, vol. ii, p. 30, 1. 20; Ibn al-Athir, vol. v, p. 316.). The reign of the Abbasids was brought to an end by Hulagu, a grandson of Chinkiz Khar. when he came in 1253 to destroy the Shicite-Ismacil Assassins (Arabic Hashshashin meaning "smokers of hashish") as well as the sunnite Caliphate. In 1258, Hulagu atrempted to have the Abbasid Caliph alMusta'sim (1242-1258) yoin him to destroy the Assassins, but no response meant open door to Huagu's invasion and destruction.

The religious term 'caliph'/ thalffa became merely a political term, sutan' sultăn (one who holds administrative power, Governor). Among the first sultans, there were the Mamluk/Mamluk sultans. Just by understanding the meaning of the term mamluk, which means "an acquired [thing or person], a slave", one would easily understand how the Mamiuk Sultans (1. 1250 1517 C.E.) came to power: As dissatisfied slaves, they revolted against their masters and occupied their posts of govermment. The term has occurred in the Qur'an $(Q$ 16:75) that recommends humane treatment of the mamink slaves (Q 4:36). Similarly, the Hadith quates the Prophet recommending on his death-bed compassion towards the mamluk/slaves. (Ahmad b. Hanbal, Musnad, iii, 119: quoted in Sh.E.I., S.V. mamluk). Like most of their predecessors, the sultans were concerned with rulership and wealth more than with the religious affairs of their subjects. Thus, the religious title, "caliph/ khalifa," was replaced by the political tille, "sultan/sultan." The sultans relied, nonetheless, on religion to confirm and solidify their authority. The regime of the sultans was described as one full of "intr[i]gue, assassination and rapine... Several of the sultans were treacherous and bloodthirsty some were inefficient or even degenerate, most of them were uncultured. AlMu'ayyad Shaykh (1412-21), a drunkard who had been bought by Barqüq from a Circasian dealer, committed some of the worst excesses." (Hitti 1943, p. 695, quoting Ibn Taghri-Birdi, vol. vi, p. 322 seq.)

In short, one can see that many of the Islamic caliphs as well as their successors, the sultans, most if not all, resorted to a violence that had, presumably, its inspirational guidelines in the Qur'an, the Prophet's Tradition, and the early Divinely Guided Successors, the Rāshidūn.

In more recent times, political leaders of various so-called "Islamic" states, such as Saudi Benladen, Iraqi Saddam Hussein, Lybian Muammar alQaddhafi, Iranian Ayatollah Khomeini, or other Middle Eastern leaders who are known for their "Islamic" political activism under the banner of Islam, did resort to jihā $d$ violence. 
In order to better understand why such continued violence in the name of Islam takes place, one needs to keep in mind that in Islam politics and religion are intertwined. At the example of Muhammad, who was a Prophet, a political and military leader, all the caliphs were religious leaders who were, at the same time, political and military leaders. With the Sultans, the title of leadership became exclusively a political and military title with no expressed religious function, though it implied it because of the all-encompassing power of the sultan. After the two World-Wars and the Franco-British mandates in the Middle East as well as in North Africa, we see independent Arab states having Muslim presidents, kings, and shahs who had no explicit religious powers heading their respective Islamic countries. Thus, one can see how Islam starting with Muhammad's message as a religious ideology that quickly became a political activity as well. Eventually, the stress on political activism with the religious jihäd overtone has become more pronounced in our times. The parties or followers of Khomeini, Qaddafi, Egyptian Jihad, Lebanese Amal, Syrian Bacath, Benladen's mujahidün of September 11, 2001 can be looked at as just sample Islamic jihäd organizations.

The zeal to convert others to one's religion is a praiseworthy attitude, especially if one truly believes that his or her religion is the best path to salvation. On the one hand, the use of violence deprives these others from their natural right to make a rational and personal choice. Also, it can deprive them from ever being converted and, consequently, from ever reaching salvation. On the other hand, if God ordered the conversion of these others by means of violence, then God, the so-called Omnipotent and Benevolent, would seem not to be truly so. He, the Creator, would have also proven to have ignored that precious human, God-like, faculty in man called "rationality" that He himself has instilled in his human creatures. Thus, for all practical purposes and in order to avoid inconsistencies in God, it would be more appropriate to allow non-Muslims to live unthreatened by the jihäd violence, hoping to see them find by other means the right path to conversion and salvation. A religion that causes violence against many innocent people, such as those victimized on September 11,2001, would appear to be a religion that is simply non-divinely inspired. Beside the religious motive of jiha $\bar{a}$ there may be other motives, political, economical, or otherwise that may have also been at the source of that violence. In concluding, one may say that if violence is taught in the Qur'an and confirmed by the praxis of Islamic history, as the above quick glimpses seem to indicate, then one may not only justifiably confirm that the September events may have well been truly jihad-motivated events, but also one may predict that there will continue to be violence as a holy function of being a Muslim.

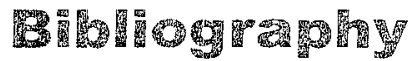

Kazi, Mahzar U. (1992). A Treasure of Hadith. Jeddah: Abul-Qasim Publishing House.

Hitti, Philip K. (1943). History of the Arabs. London: Macmillan and Co.

Shorter Encyclopedia of Islam (1953-1974). Ithaca: Cornell University Press. 
The Ierusalem Bible (1966). New York: Doubleday. (Other editions may also be used).

'Ali, 'Abdullah Yũsuf, Trans., comment. (1997). The Meaning of the Holv Qur'ân. Beltsville, Maryland: Amana Publications.

Dr. Gabriel Lahood has taught Philosophy and Religion at various colleges and universities in the U.S. and overseas. His specialization focuses on the concept of human agency in Aristotle (ancient Greek philosopher) and Avicenna (medieval Muslim philosopher) and on contemporary issues of freewill vs. determinism. He read many papers at conferences and published several articles on the subject of agency as well as on Islam and on specific issues within the field of philosophy of religion. Two book-size publications are underway, one (Avicenna's Secret of Destiny) is being considered by Marquette University Press and is expected to be published in 2003. The other (The Earrings of God) is in search for a publisher. Presently, Dr. Lahood is a Visiting Professor at the College of he Bahamas. 